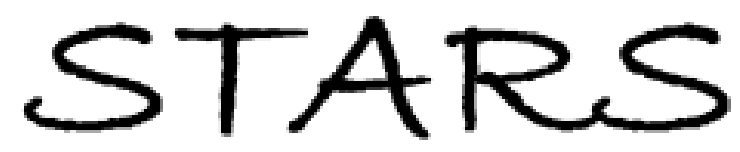

University of Central Florida

STARS

$1-1-2007$

\title{
Adaptive capacity and learning to learn as leverage for social- ecological resilience
}

\author{
Ioan Fazey \\ John A. Fazey \\ Joern Fischer \\ Kate Sherren \\ John Warren
}

See next page for additional authors

Find similar works at: https://stars.library.ucf.edu/facultybib2000

University of Central Florida Libraries http://library.ucf.edu

This Review is brought to you for free and open access by the Faculty Bibliography at STARS. It has been accepted for inclusion in Faculty Bibliography 2000 s by an authorized administrator of STARS. For more information, please contactSTARS@ucf.edu.

\section{Recommended Citation}

Fazey, loan; Fazey, John A.; Fischer, Joern; Sherren, Kate; Warren, John; Noss, Reed F.; and Dovers, Stephen R., "Adaptive capacity and learning to learn as leverage for social-ecological resilience" (2007). Faculty Bibliography 2000s. 7114.

https://stars.library.ucf.edu/facultybib2000/7114

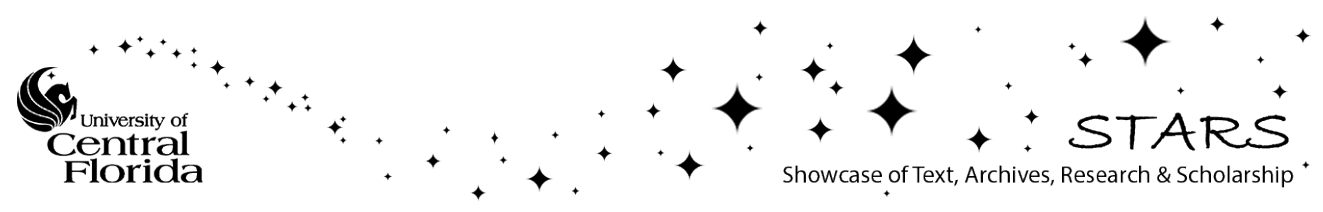




\section{Authors}

Ioan Fazey, John A. Fazey, Joern Fischer, Kate Sherren, John Warren, Reed F. Noss, and Stephen R. Dovers 


\title{
Adaptive capacity and learning to learn as leverage for social-ecological resilience
}

\author{
Ioan Fazey ${ }^{1 *}$, John A Fazey ${ }^{2}$, Joern Fischer ${ }^{3}$, Kate Sherren ${ }^{3}$, John Warren ${ }^{1}$, Reed F Noss ${ }^{4}$, and Stephen R Dovers ${ }^{3}$
}

\begin{abstract}
Adaptive capacity is increasingly recognized as essential for maintaining the resilience of social-ecological systems and for coping with environmental change. Four main requirements enable societies to successfully adapt to change: (1) the will and intention to maintain social-ecological resilience, (2) knowledge about current problems and the desired direction of change, (3) proactive behavior, and (4) the capacity to change existing patterns of behavior. The adaptive capacity of societies can be greatly enhanced by fostering the adaptive capacity of their individual members. Considerable knowledge about how to foster the adaptability of individuals exists in the science of education and in cognitive and social psychology. Developing the ability to learn flexibly in a variety of ways, contexts, and circumstances is an important element of developing adaptive capacity. The widespread implementation of modern teaching approaches in the education sector could make a substantial contribution to building and maintaining social-ecological resilience.
\end{abstract}

Front Ecol Environ 2007; 5(7): 375-380

$S_{\text {iningse }}^{\text {us }}$ ustainability science increasingly recognizes the importance of adaptive capacity for maintaining the resilience of social-ecological systems (Gunderson and Holling 2002; Adger 2003; Folke et al. 2005). Resilience is defined as the amount of disturbance that a system can absorb without undergoing major change in its character or function (Gunderson and Holling 2002), and is dependent on a system's adaptive capacity, or its ability to reorganize and renew itself in the face of change (Gunderson and Holling 2002; Carpenter and Folke 2006). For example, human societies must respond flexibly to continually shifting external factors to maintain social resilience, such as adapting to global market forces to sustain economic activity (Folke et al. 2005; Carpenter and Folke 2006).

\section{In a nutshell:}

- The ability of individuals to adapt to changing circumstances and to alter their behavior is important for building and maintaining social-ecological resilience

- Research suggests that, to become adaptive, individuals must learn how to learn flexibly by varying the way skills and abilities are practiced

- Applying modern, research-led teaching practices contributes to the development of adaptive capacity in individuals

- A robust alliance between ecologists and educationalists will contribute substantially to building and maintaining social-ecological resilience

${ }^{1}$ Institute of Rural Sciences, University of Wales, Aberystwyth, Ceredigion SY23 3AL, UK *irf@aber.ac.uk); ${ }^{2}$ Oxford Learning Institute, University of Oxford, Oxford OX1 1PT, UK; ${ }^{3}$ Fenner School of Environment and Society, Australian National University, Canberra 0200, Australia; ${ }^{4}$ Department of Biology, University of Central Florida, Orlando, FL 32816
Similarly, ecological systems have a limited ability to renew themselves after perturbation, such as in the reorganization of tropical forests after cyclones (Elmqvist et al. 2001). The adaptive capacity of ecosystems appears to be higher if there is a high diversity of functional groups and a high diversity of different ways in which species within a particular functional group can respond to environmental change (Elmqvist et al. 2003; Carpenter and Folke 2006).

The resiliences of ecological and human social systems are interdependent (Figure 1). Ecological systems provide many services upon which humans depend (eg air and water purification, flood and storm protection). Without these services, the resilience of human social systems is compromised (MA 2005). Similarly, without resilient social structures that regulate human environmental impacts, the functional dynamics of ecological systems can change (Diamond 2005; MA 2005). Understanding how to transform human societies so that they can respond flexibly and appropriately to new information and circumstances is therefore a vital component of achieving a sustainable future (Adger 2003; Folke et al. 2005).

Adaptive capacity in human societies requires sufficient resources and appropriate institutional structures (Yohe and Tol 2002). Nevertheless, reform of the institutional "hardware" needed to achieve sustainability, or any other social goal, is unlikely to come about without the equally necessary "software", which includes the behavior, knowledge, and skills of the people involved (Dryzek 1996). Transformation toward more sustainable practices will therefore be much more likely if the individuals who make up a society can accept change and modify their personal behavior (Keen et al. 2005). This provides the basis for shaping and creating new and adaptive institu- 


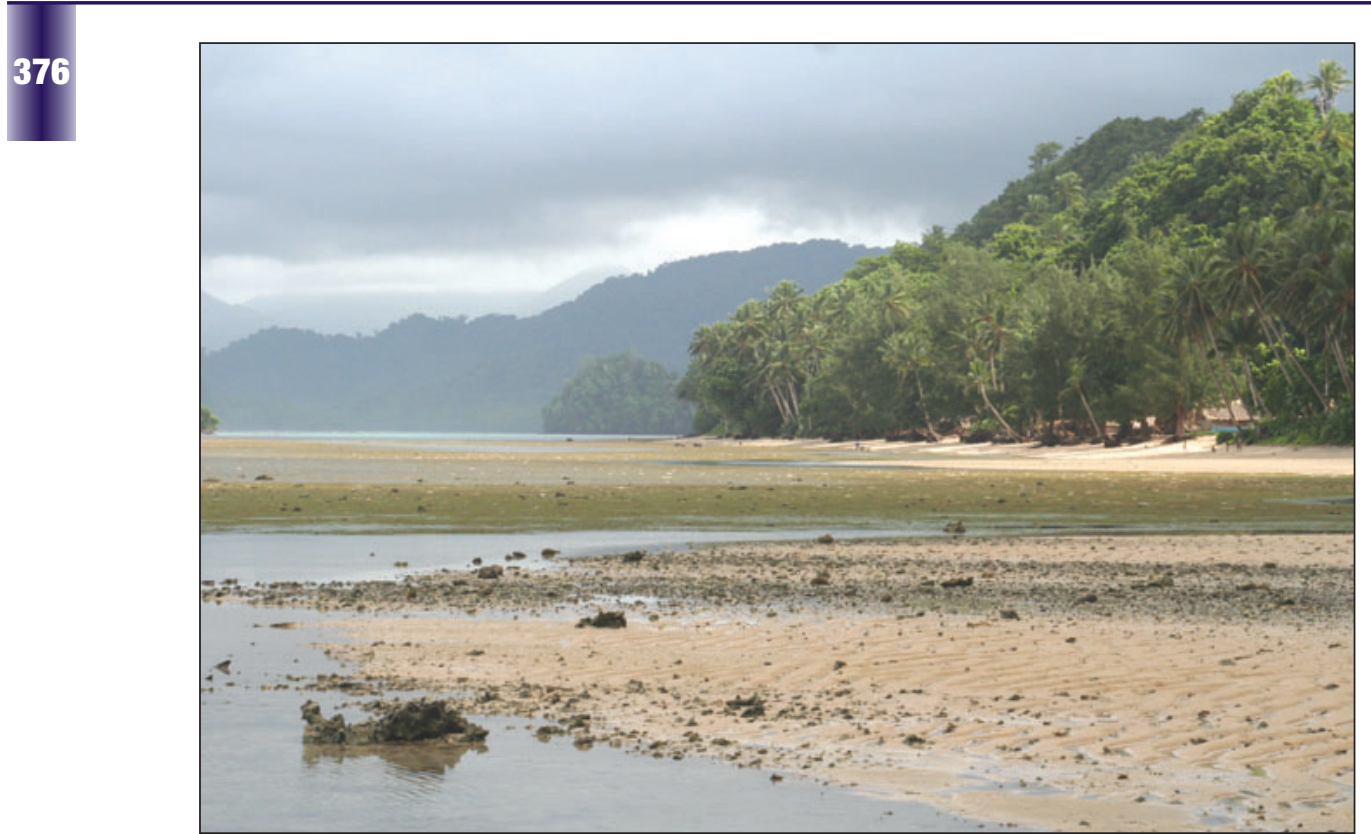

Figure 1. Nowhere are human and ecological systems more interdependent than in small island nations like the Solomon Islands, which today are under pressure from environmental and social phenomena at all scales.

tions (Connor and Dovers 2004; Rushmer et al. 2004), which in turn create the potential for broader changes in the societies in which institutions are embedded, including abandonment of behaviors that have negative impacts on ecosystems.

Individuals and the societies they form are linked in complex ways. In simple terms, individuals are embedded within, and constrained by, the communities and societies of which they are a part, with different social and political structures fostering or impeding the direction of change. Societies, in turn, are embedded within, and constrained by, natural ecosystems and the services they provide (Lowe 2005). Yet changes in the behavior of individuals can also result in changes at larger community and societal scales. This is highlighted by the positive association between the level of trust individuals have for one another and the favorable performance of governments, for instance in terms of accountability, flexibility, and innovation in policy making, long-range planning, and the inclusion of stakeholders in the development of strategic plans (Brehm and Rahn 1997; Knack 2002). Notably, many strategies used to promote societal change recognize that not all individuals have equal power in influencing the process. In large-scale development and educational programs, substantive societal change is promoted by targeting the behavior of key individuals who strongly influence the individual behaviors of a large number of others (UNESCO 2005; UNICEF 2006). There is now considerable knowledge from the science of education regarding development of individuals' capacity to learn about and adapt to change. This has important implications for building and maintaining social-ecological resilience.
Adaptive human societies and social-ecological resilience

The adaptive capacity of human societies for maintaining social-ecological resilience has four main requirements. These are: (1) the will to maintain social-ecological resilience, (2) knowledge about the impacts of current behavior and the direction of change, (3) proaction, and (4) the capacity to change behavior (Figure 2).

First, societies must have the will and intention to maintain resilience; otherwise, there is no desire to push the boundaries of knowledge or to change behaviors appropriately. This is required at an individual level to reduce the aggregated impacts of unsustainable behavior, and at a societal level to ensure that a suitable environment exists in which appropriate adaptation can occur. Without sufficient will and intention for maintaining resilience at a societal level, policies championed by key individuals, aimed at achieving more sustainable activity, will not be accepted by politicians or society as a whole.

Adaptability by itself does not necessarily promote resilience. Human adaptations that have enabled technological advances and more efficient resource extraction have also resulted in many of today's environmental and social problems (Diamond 2005; Berkes et al. 2006). Intention for sustainability therefore requires education programs that promote broad awareness, recognition, and knowledge of sustainability and its implications, including attention to the subject of change itself (Huckle and Sterling 1996). Such programs need to be sufficiently flexible to incorporate and adapt to new understanding that arises from education and sustainability research (Carpenter and Folke 2006).

Second, it is important to understand the social-ecological impacts of current behavior and to disseminate information on how best to achieve the desired direction of change (Carpenter 2002). Sustainability science that tackles a broad range of cross-scale issues, integrates many different types of information, and tightly couples research with practice, is essential to this process (Kates et al. 2001). Learning needs to be continuous, and sustainability science must adapt to the emergence of new questions and changing social compacts (Folke et al. 2005).

Third, continuous questioning about the sustainability of individual and societal activities enables bold decision making in the face of uncertainty (MA 2005). Such proaction creates the future, as opposed to simply reacting to past or current events. Reactive behavior is insufficient for maintaining social-ecological resilience because, by the time the impacts of past decisions come to light, it is 
usually too late to avoid them. An adaptive, resilient society requires a critical mass of people who value proactivity; otherwise, decision makers will be unable to set new directions and help society to break out of undesirable patterns of behavior (Wood 2004).

Finally, sustainability problems have systemic causes and require equally systemic behavioral, policy, and institutional responses (Dovers 1997). Societies must therefore be able to accept change and modify broad patterns of behavior to treat the causes of problems rather than just the symptoms. At one extreme, behavior can be modified to fully align it with changing external conditions, such as rebuilding houses away from floodplains in response to flooding, or avoiding car use to reduce $\mathrm{CO}_{2}$ emissions in response to climate change. At the other extreme, adaptation can buffer against the impacts of change (eg building higher flood defenses or resorting to more powerful air conditioning to cope with rising temperatures).

Adaptation by buffering is less desirable because it tends to disconnect people from their environment and reduces opportunities for learning about the consequences of their activities. It also tends to result in the reinforcement of problems. Flood defenses, for example, reduce smaller frequent floods and perception of risk. Development in flood zones then tends to increase, reducing future options for change and reinforcing perceptions of the need for flood defenses. With increased development, there is less flood storage capacity in the river corridor for natural flooding to occur, and surrounding land often subsides as it dries. Pressure on defenses increases, until a large flood finally breaks through, often with catastrophic consequences, as highlighted by the flooding of New Orleans in August 2005 (Congleton 2006).

Human responses to environmental problems tend to involve little change in the behaviors that reinforce problems. Although adapting to climate change by using hybrid-electric cars helps to reduce $\mathrm{CO}_{2}$ emissions, it does not result in changes in driving behavior. Pollution is reduced, but other beliefs inconsistent with ecological resilience may continue to be reinforced, such as the expectation of being able to regularly and quickly travel large distances, resulting in a tendency for people to live further from work, a perceived need for more roads, and a decline in locally produced foods.

Humans are notoriously bad at changing the ways they think and behave. This is partly due to powerful social barriers, such as dependence on economic growth, cars, and oil, which lock societies into particular patterns of behavior and make change difficult. However, these barriers are often the result of past decisions and actions that, on the surface, appeared to provide solutions, as in the case of levee construction on the Mississippi delta in the 18th and 19th centuries (Congleton 2006) and as in many other maladaptations in the relationship between humans and their environment (Boyden 1987). This highlights the importance of individuals' ability to question the appropriateness of their actions and to alter their personal behavior accordingly, and then to influence broader societal change.

Psychological barriers that inhibit changes in thinking and behavior are therefore important constraints to social-ecological resilience. They include the common tendency to be defensive, the assumption that other people perceive the world in the same way, and a focus on relatively minor issues that have immediate personal impact rather than an appreciation of the bigger picture (Morris and Su 1999). These barriers partly stem from natural evolutionary tendencies toward self-interest (Dawkins 1976), but are also learned through social interactions (Del Collins 2005). The capacity for learning implies that people can also learn to overcome common psychological barriers and develop greater capacity to accept the need to change. Such acceptance is not easy to achieve or to translate into real behavioral changes. However, these learning processes often provide a basis for enhancing social interactions to improve the effectiveness of conservation or development programs and for resolving conflict (Morris and Su 1999; Pretty 2003; Del Collins 2005). 


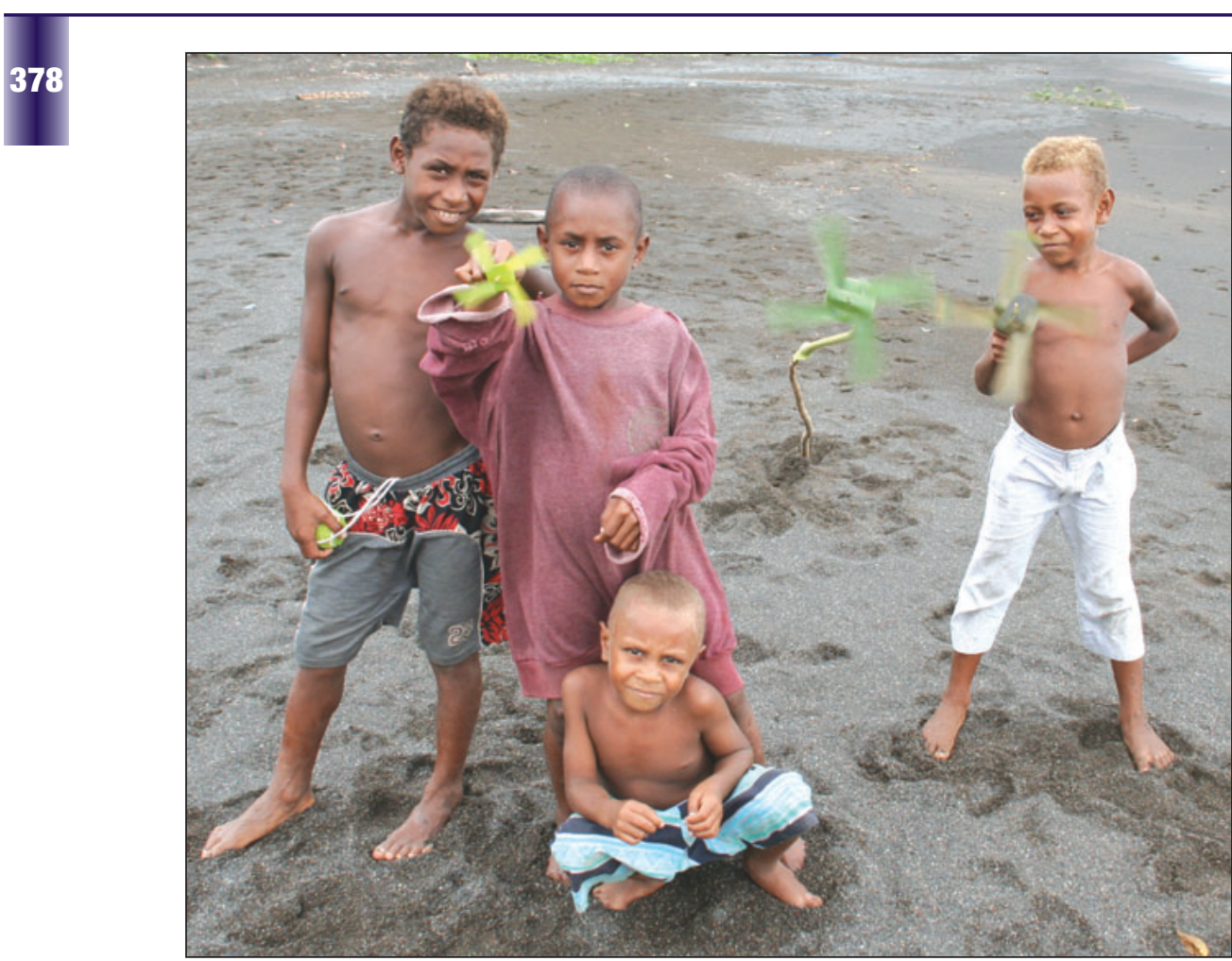

Figure 3. Children in the Solomon Islands play with home-made windmills.

continuously learn from their experiences and improve performance. They accept that their understanding will always change. These underpinning beliefs, attitudes, and associated behaviors can be both learned and taught (Perkins and Grotzer 1997). Furthermore, while they enhance adaptive potential, they are also reinforced by it. This is especially true when elements of frequent and deliberate practice, effective reflection, and the acceptance of different perspectives are themselves practiced in a variable, reflective way. Learners become more able to flexibly learn in new situations, and as with learning anything, the process becomes natural, unconscious, and automated. A person who learns how to learn will eventually develop greater openness to change and will become an adaptive expert learner (Fazey et al. 2005).

This has profound implications across all sectors of society and for social-ecological resilience. It not only implies

- Adaptive expert learners and education for social-ecological resilience

Over the past 35 years, important insights into how people can learn to be more adaptive have come from the science of education and studies of expertise. In the mid1980s, the term "adaptive expertise" was first used to highlight the flexibility of expert Japanese sushi chefs, who demonstrated creativity and adaptability in response to external demands, as opposed to other experts who were technically very proficient, but generally stuck to routines and followed fixed recipes (Hatano and Inagaki 1986). Other studies have described adaptive experts as being "highly competent" rather than "merely skilled", or being "virtuosos" rather than "artisans" (Bransford et al. 2000). Such differences exist across a range of professions, from historians to information system designers (Bransford et al. 2000), and across a range of physical, social, and intellectual skills (Figure 3), including the ability of conservation managers to learn about and manage complex dynamic ecosystems (Fazey et al. 2005).

These studies, which provide insight from cognitive and social psychology, suggest that the development of expertise requires extensive practice and reflection on performance, using different thinking strategies (Perkins and Grotzer 1997). The key element to developing adaptability, however, is varying the way that something is practiced. By adding variation to practice, people gain the experience of different perspectives. This enhances transferability of skills, builds confidence in dealing with new situations (Schwartz et al. 2005), and results in new cognitive abilities (Bialystok et al. 2005).

Adaptive experts exhibit a strong proactive desire to that individuals have the ability to change their behavior and outlook, but also promotes a proactive society with improved knowledge via the development of empathetic, questioning individuals with characteristics similar to those of effective sustainability scholars (Antonacopoulou 2004; Bammer 2005). That is, developing the flexible learning ability of individuals, as described above, fosters knowledge generation, a proactive outlook, and the ability to change. Education for sustainability, which promotes the development of flexible learning abilities and dispositions across all disciplines and ages, is therefore essential to complement education about sustainability, which builds awareness, willingness, and intent. This fundamental link between social-ecological resilience and educational processes, one that promotes critical thinking, holistic vision, and acceptance of the diversity of values, is now well recognized (Huckle and Sterling 1996; UNESCO 2005).

Education and psychological research already provide important knowledge about how to teach and develop adaptive qualities in individuals. Many of the desired learning outcomes from an education perspective are synonymous with those for promoting adaptive capacity for building and maintaining social-ecological resilience. For example, research suggests that more attention must be given to teaching metacognitive skills, such as practicing different ways of thinking in a variety of contexts, and less emphasis placed on trying to fill students with a large volume of facts and knowledge (Bransford et al. 2000).

Unfortunately, there are major difficulties with the application of education research, given the many existing political, social, and institutional barriers. In the UK, 
for example, educational policies anticipating a future knowledge-based, rather than production-based economy have resulted in dramatic increases in the number of students entering higher education. At the same time, the variation in students' backgrounds has increased through policies geared at widening participation. These changes have been paralleled by increased accountability, but not by comparable increases in funding. Academic institutions have adapted in buffering-type ways, by increasing class sizes, employing less qualified staff, and using automated methods of assessment. Consequently, many students and teachers have been forced to adopt learning and teaching approaches that promote short-term retention of information and the reproduction of the accepted products of other people's thinking.

Some of these barriers can be overcome, as suggested by the excellent examples of effective, research-led teaching (Baillie and Vanasupa 2003; Handelsman et al. 2004; Lieblein et al. 2004; Netting 1994). This is easier when changes are perceived as opportunities (eg viewing increased variation in student backgrounds as a way of exposing them to a greater variety of perspectives). Nevertheless, more emphasis on implementing what is known from the science of education, together with appropriate resources across a wide range of educational spheres, is required if education policies and teaching are to contribute substantially to promoting adaptive capacity for social-ecological resilience.

\section{Ecologists and educationalists}

The maintenance of ecological processes that are essential for human societies is dependent on the ability of individuals and societies to adapt appropriately, to align their behavior with changing conditions, and to promote institutional change. This dependence will increase during this century, as global rates of technological, economic, social, and environmental change also soar. There is increasing recognition of the need for greater connections across the natural sciences, social sciences, and humanities. Scholarship on interdisciplinarity is emerging to facilitate such connections in research and education for sustainability (Barnett et al. 2003; Bammer 2005). Specifically, a robust trans-disciplinary alliance between ecologists and educationalists is required to promote the development of adaptive behavior of individuals in ways that contribute to building and maintaining social-ecological resilience. Strengthening the ties between the philosophically different disciplines of ecology and education will require many people to re-examine their underlying assumptions, including those about the validity of different forms of knowledge and about what it means to learn. This will be much easier for those who have already been educated to accept change.

\section{References}

Adger WN. 2003. Social capital, collective action, and adaptation to climate change. Econ Geogr 79: 387-404.

Antonacopoulou E. 2004. On the virtues of practising scholarship: a tribute to Chris Argyris, a "timeless learner". Manage Learn 35: 381-95.

Baillie C and Vanasupa L. 2003. Navigating the material world: a guide to understanding materials behavior. San Diego, CA: Academic Press Inc.

Bammer G. 2005. Integration and implementation sciences: building a new specialization. Ecol Soc 10: 6.

Barnett J, Ellemor H, and Dovers S. 2003. Interdisciplinarity and sustainability. In: Dovers S, Stern DL, and Young M (Eds). New dimensions in ecological economics: integrated approaches to people and nature. Cheltenham, UK: Edward Elgar.

Berkes F, Hughes TP, Steneck RS, et al. 2006. Globalization, roving bandits, and marine resources. Science 311: 1557-58.

Bialystok E, Craik FIM, Grady C, et al. 2005. Effect of bilingualism on cognitive control in the Simon task: evidence from MEG. Neuroimage 24: 40-49.

Boyden SV. 1987. Western civilization in a biological perspective: patterns in biohistory. Oxford, UK: Clarendon Press.

Bransford JD, Brown AL, and Cocking RR. 2000. How people learn: brain, mind, experience, and school. Washington, DC: National Academy Press.

Brehm J and Rahn W. 1997. Individual-level evidence for the causes and consequences of social capital. Am J Polit Sci 41: 999-1023.

Carpenter SR. 2002. Ecological futures: building an ecology of the long now. Ecol 83: 2069-83.

Carpenter SR and Folke C. 2006. Ecology and transformation. Trends Ecol Evol 21: 309-15.

Congleton RD. 2006. The story of Katrina: New Orleans and the political economy of catastrophe. Public Choice 127: 5-30.

Connor R and Dovers S. 2004. Institutional change for sustainable development. Cheltenham, UK: Edward Elgar.

Dawkins R. 1976. The selfish gene. Oxford, UK: Oxford University Press.

Del Collins M. 2005. Transcending dualistic thinking in conflict resolution. Negotiation J 21: 263-80.

Diamond J. 2005. Collapse: how societies choose to fail or survive. London, UK Penguin Books, Ltd.

Dovers S. 1997. Sustainability: demands on policy. J Publ Pol 16: 303-18.

Dryzek JS. 1996. The informal logic of institutional design. In: Goodin RE (Ed). The theory of institutional design. Cambridge, UK: Cambridge University Press.

Elmqvist T, Folke C, Nystrom M, et al. 2003. Response diversity, ecosystem change, and resilience. Front Ecol Environ 1: 488-94.

Elmqvist T, Wall M, Berggren AL, et al. 2001. Tropical forest reorganization after cyclone and fire disturbance in Samoa: remnant trees as biological legacies. Conserv Ecol 5: 10.

Fazey I, Fazey JA, and Fazey DMA. 2005. Learning more effectively from experience. Ecol Soc 10: 4.

Folke C, Hahn T, Olsson P, and Norberg J. 2005. Adaptive governance of social-ecological systems. Annu Rev Environ Resourc 30: 441-73.

Gunderson LH and Holling CS. 2002. Panarchy: understanding transformations in human and natural systems. Washington, DC: Island Press.

Handelsman J, Ebert-May D, Beichner R, et al. 2004. Scientific teaching. Science 304: 521-22.

Hatano G and Inagaki K. 1986. Two courses of expertise. In: Stevenson H, Azuma H, and Hakuta K (Eds). Child development and education in Japan. New York, NY: WH Freeman.

Huckle J and Sterling S (Eds). 1996. Education for sustainability. London, UK: Earthscan Publications Ltd.

Kates RW, Clark WC, Corell R, et al. 2001. Sustainability science. Science 292: 641-42.

Keen M, Brown V, and Dyball B. 2005. Social learning in environmental management. London, UK: Earthscan. 
Knack S. 2002. Social capital and the quality of government: evidence from the states. Am J Polit Sci 46: 772-85.

Lieblein G, Ostergaard E, and Francis C. 2004. Becoming an agroecologist through action education. Int J Agric Sustain 2: 147-53.

Lowe I. 2005. Sunshine, solar energy, social factors and sustainability. In: Sherratt T, Griffiths T, and Robin L (Eds). A change in the weather: climate and culture in Australia. Canberra, Australia: National Museum of Australia Press.

MA (Millenium Ecosystem Assessment). 2005. Ecosystems and human well-being: synthesis. Washington, DC: Island Press.

Morris MW and Su SK. 1999. Social psychological obstacles in environmental conflict resolution. Am Behav Sci 42: 1322-49.

Netting NS. 1994. Can an individual change society? Empowering students in a context of social reality. Teach Sociol 22: 200-03.

Perkins DN and Grotzer TA. 1997. Teaching intelligence. Am Psychol 52: 1125-33.

Pretty J. 2003. Social capital and the collective management of resources. Science 302: 1912-14.

Rushmer R, Kelly D, Lough M, et al. 2004. Introducing the learning practice: III. Leadership, empowerment, protected time and reflective practice as core contextual conditions. J Eval Clin Pract 10: 399-405.

Schwartz DL, Bransford JD, and Sears D. 2005. Efficiency and innovation in transfer. In: Mestre JP (Ed). Transfer of learning from a modern multidisciplinary perspective: research and perspectives. Portland, OR: Information Age Publishing.

UNESCO (United Nations Educational, Scientific and Cultural Organisation). 2005. United Nations decade of education for sustainable development 2005-2014: draft international implementation scheme. Paris, France: UNESCO.

UNICEF (United Nations Children's Fund). 2006. China: education and child development. www.unicef.org/china/education_child_development_559.html. Viewed 5 June 2007.

Wood P. 2004. Intergenerational justice and curtailments on the discretionary powers of government. Environ Ethics 26: 411-28.

Yohe G and Tol RSJ. 2002. Indicators for social and economic coping capacity: moving towards a working definition of adaptive capacity. Glob Environ Change 12: 25-40. 